\title{
Quality assurance in vocational higher education: A case of Macau
}

\author{
Rachel Wai-Yi Cheung* \\ Macau Institute of Management, Macau, China
}

\author{
Keywords \\ Quality Assurance (QA) \\ Facility management \\ Accounting \\ Professional accreditation \\ Covid-19 pandemic \\ Greater bay area
}

Received: 10 January 2020

Accepted: 16 March 2020

Published: 29 September 2020

\begin{abstract}
This paper reports an investigation of perception on higher education students in Macau, particularly in vocational higher education. Higher education institutions in Macau have to adopt the new Macau Higher Education Law in relation to the QA requirements. By adopting a quantitative research method, a questionnaire was distributed in hard copy. Students' data were drawn from one higher education institution in Macau, which offers most of its programs career-related vocational basis. Participants are required to self-report his/her perception of QA and rate the importance of a set of questions about professional accreditation, program curriculum. Major findings are: nearly half of the respondents never heard of any QA, or they heard of, but they do not know what it is about. More than $70 \%$ of the respondents view it as important or very important to have the study programs accredited by professional associations or by academic accrediting agencies. Over $70 \%$ of respondents studying at careerrelated vocational programs perceive that it is important or very important to have their programs professional or academically accredited. While their counterparts are studying at a less career-related program, only $60 \%$ of them perceive important or very important. $95 \%$ of accounting and $89 \%$ of facility management students opined that the curriculum should match the respective profession/ job needs. Based on the findings, some key recommendations are made. These include having more programs accredited by respective professional associations and designed according to profession/job needs. In addition, the findings here do give insights for re-training directions for the outbreak of COVID-19 in adult education. This further helps students adapting this ever-changing world which is one of the aims of vocational higher education.
\end{abstract}

(C) 2020 The Author(s). Published by TAF Publishing

\section{INTRODUCTION}

On the basis of the changing demographic patterns, the educational needs of workforce and the growth of knowledge in a learning based society, higher education institutions had been evolved and redefined its relationship between the adult learner and the society (Di Rienzo, 2019). Higher education acts to educate life of the society. Society is changing, changes in society demands a change in educational goals as well, with the technological change and increased competition at work, there is an interest in promoting learning throughout adult life (Cheung, 2019a; HM Government, 2017). Due to the recent development in learning needs, one part of higher education is vocational education and it has a responsibility to the society to prepare students to be able to face changes in their community (Yulastri, Hidayat, Ganefri, Edya, \& Islami, 2018). For vocational-based higher education programmes, besides the academic accreditation, programmes usually seek accreditation from their respective professional associations such as, accounting, nursing, surveying and many more.

Before going into details of the two kinds of accreditations (academic and professional) commonly sought by the career-related vocational programmes, I would like to describe the QA first. QA is a borrowed term from business sector to the higher education section in the 1980s (Elassy, 2015; El-Khawas, 2013). Harvey (2011) defined QA in higher education as "a process of establishing stakeholder confidence that provision (input, process and outcomes)

\footnotetext{
* corresponding author: Rachel Wai-Yi Cheung

†email: rachelcheung@mma.org.mo
} 
fulfils expectations or measures up to threshold minimum requirements" (Harvey, 2011). Biggs (2001) study defined QA into two concepts: retrospective and prospective, the former focus on accountability and the latter on improvement theme. Retrospective QA implies that quality can be measured easily by using a check list of external standards. The prospective QA is about whether the now and future of teaching and learning can continue to fit the purpose of an institution. In Macau, as it is just introduced the QA in higher education, under Biggs's interpretation of the QA system, Macau's higher education system is in the retrospective QA approach. Back to the career-related vocational programmes, they become a prominent features of higher education in the future as it supports the growing demand for graduates especially in middle income countries (Rajadurai, Sapuan, Daud, \& Abidin, 2018). In globalization context, vocational higher education would take another responsibility to train adult or young adult so to increase their productivity and readiness to work in the local and global employment market (Yulastri et al., 2018). These adult/young adult should learn and update their skills in order to remain globally competitive (Köpsén, 2020; Mandal, 2013; Owusu-Agyeman, 2017). On the other hand, the competitive job market also created additional complexity for the employers to identify relevant knowledge and skills they needed (Gjorgov \& Cripps, 2018). Many people do believe that having received higher education degrees would raise job opportunity and also would have a better career (Hanh, Nga, Loan, \& Viet, 2019). Understanding this global trend, many higher education institutions (in particular those provide adult education) would seek professional accreditations from relevant professional associations for their career-related vocational programmes. This kind of professional accreditation usually match the academic curriculum with their professional requirements. Professional association could provide a supplement to the curriculum and a connection to careers (Keniry, 2020). Through professional qualification accreditation, the knowledge learnt by the learners and the educational requirements required by the profession are more in-line and consistent (Hanh et al., 2019). Graduates of an accredited programmes meant that they are able to achieve the required competence as a profession (Wilby, Alamri, \& Monfared, 2019). Graduates from accredited programmes impact job, meanwhile, students of developing countries can have higher mobility transformed to developed countries (Gjorgov \& Cripps, 2018; Hanh et al., 2019).

\section{Quality Accreditation}

Besides accreditation from a professional association, career-related vocational programme in higher education will seek academic accreditation as well. In higher education, academic quality accreditation is a process which means an external accrediting agency evaluates a curriculum (or an higher education institution) and has the authority to recognize if the curriculum (or an higher education institution) has met the necessary predetermined requirements and standards. Students, in general, welcome their study programmes being accredited, they had positive perception of international accreditation, as they believed accreditation increases the reputability of the programmes, ensure standards are maintained, and provides opportunities related to careers and postgraduate studies. Almost all of the participants (students) in Wilby et al. (2019) study give credit for having better job opportunity upon graduation because of the accreditation. They also find that students perceive accreditation to influence the quality of education. The accreditation can positively influence education and practice (Wilby et al., 2019).

In additional to the above, when I am writing this paper, there is an outbreak of Covid-19 pandemic over the world, and the employment market had been shaken and unemployment figures have risen steeply in many countries (Gössling, Scott, \& Hall, 2020). Due to the job nature change, people who would like to stay in the job market need to acquire new knowledge or skills. The pace of change and uncertainty of the Covid-19 highlights the need of the country/city and job seeker flexibility (Orrell, Bishop, \& Hawkins, 2020). Therefore, re-training might be applied. Would the unemployed or those who still staying in the job market would consider to be re-trained? Would they like to study an advanced degree so to have higher competitive skills edged their counterparts? If so, what kinds of studies would they pursue, would those be job-related? Although the data of my study was taken before the outbreak of the pandemic, the responses from the respondents (students) who are learning adult studying at career-related vocational or non-career-related programmes, may able to give an insight to answering these questions.

\section{Research Purpose}

The purpose of vocational education training is to develop essential skills for progression and to provide entry-routes and initial training for occupation and careers. There are significant numbers of adults engaged in programmes including college courses that lead to qualifications within this category (Lester, 2015). Just about two years ago, 
Macau passed a new education law on QA and accreditation. I do find a modest body of literature exists on professional accreditation, academic accreditation, students perception in many developed countries or countries that just started the mandatory academic accreditation. However, there is no study carried out on the student's perception on academic accreditation and professional accreditation in Macau. Macau places great emphasis on gaming and tourism industry (Alves, Lok, Luo, \& Hao, 2020). After the outbreak of Covid-19 pandemic, it is noted that there are huge risks of Macau economy's over reliance on gaming tourism (Reuters, 2020). This study intended to explore the higher education (career-related and non-career related) students' perception on QA and accreditation. It is hoped that these results will give the higher education providers or the education authority to aware of students' (i.e., major stakeholders) perception on QA and accreditation.

With this in mind, this paper is organized into six sections, the first section is the introduction, followed by the literature review. Section 3 and 4 contain the research questions development and method. Finally, Section $5 \& 6$ are findings and the conclusion of the study.

My study, though a comparative small study, has a few significances contribute some new ideas on students' perception on QA. I find that nearly half of the responding students self-reported that they do not have much knowledge on QA but over $70 \%$ of those studying in more career-related programmes (accounting, facility management and human resources management) perceive that it is important or very important to have their programmes being academic accredited or professional accredited (refer to RQ2 and RQ3). It means that students welcome the QA process although they may not understand the term of QA. (note: accreditation on academic or professional is a QA process). However, only $60 \%$ of their counterparts (studying at a less career-related programmes--Management), perceive it is important or very important to have their programme being academic or professional accredited. I can say that students studying career-related vocational programmes require their programmes being accredited more than their counterparts.

\section{LITERATURE REVIEW}

QA

The growth of the knowledge-based economy world-wide has led commercial and business sectors to grab for the best brains, meanwhile, education sector also try to train the best brains, and knowledge is increasingly a commodity that moves between countries (Grapragasem, Krishnan,
\& Mansor, 2014; Knight, 2003). The General Conference of the United Nations Educational, Scientific and Cultural Organization (UNESCO), in November 2015, had made the following recommendation concerning technical and vocational education and training ("TVET"). For QA, they requested the member states should foster an environment for high-quality TVET, and establish a system for QA in TVET based on participation by all relevant stakeholders. The quality of higher education is the development of effective systems for QA within a higher education institution.

\section{Against QA}

In Elassy (2015) study, he stated some descriptions about the term "quality" from previous literatures, and among them, academics' perceptions of quality is meaningful to be addressed here. He stated that academics opposed QA mechanisms because they had an idea that QA did not able to assure quality in a meaningful way but it did create lots of additional workload burden (Adams, Brauer, Karas, Bresnahan, \& Murphy, 2004; Elassy, 2015).

One may easily argue that QA is a burden, as it involves lot of details, including documentation, evidence gathering and keeping, meetings and minutes recording and human capital. QA in Macau is a newly developed mechanism. There is known additional burden to the higher education institutions, But by law, all higher education institutions have to set up and follow this new QA.

\section{Higher Education Regulation}

Higher education institutions have been forced to transform themselves in light of a world that it continuously facing the challenges of globalization (Meidrina, Mawaddah, Siahaan, \& Widyasari, 2017; Ooro, 2013). Over the past 10 years, Macau higher education expanded impressing with the increase in the number of institutions as well as the number of students. With the development of Macau, higher education has become more and more popular. The enrollment rate of high school graduates has increased from about $70 \%$ in the initial period after the Handover (i.e., 1999) to more than $90 \%$ in recent years. While for global overall expansion of higher education, the international development of vocational higher education will also be expanded (Marginson, 2016; Ryan, Gwinner, Mallan, \& Livock, 2017).

The expansion is increasing accessibility to higher education as it provides opportunities for social mobility to opportunity for those are not able to continue their study in higher education, it also provides opportunity for people to move from one socio-economic positon to another (Avis, 2012). Higher education in Macau is formulated through 
public and private institutions, and there are 10 higher institutions in Macau. Four are publicly funded and the remaining are private institutions. Higher Education Bureau is a government office and responsible for supporting, following up and developing matters relating to higher education in Macau.

The Macau SAR Government attaches great importance to the continuous enhancement of the quality of higher education. In addition to the establishment of a higher education quality evaluation system, it has joined three international higher education QA organizations in recent years, including the Higher Education Quality Assurance Network (INQAAHE), the Asia Pacific Quality Assurance Network (APQN) and the Higher Education Quality Assurance International (CIQG) under the US Higher Education Accreditation Council (CHEA) (Higher Education Bureau, 2019).

Meanwhile, in order to enforce the Higher Education Institutions to follow the QA requirements, Macau Government established a number of new Higher Education Regulations and they took effect on 8 August, 2018. Besides those regulated policies, committees, funding, credits offerings in institutions, QA (regulation no. 17/2018) is one of the regulations. This is the first time Macau introduces QA in higher education. This QA system is to ensure the healthy growth and competitiveness of Macau's higher education institutions among their counterparts over the world. The regulation governs QA on both the institution and programme levels. For the QA matters, key stakeholders may include: lecturers, students, administrators, graduates, employers, professional bodies (Ansah, 2015).

\section{RESEARCH METHODOLOGY}

\section{Research Questions Development}

With reference to Macau Administration Regulation No. 17/2018 -Higher Education Quality Evaluation System, it states the aim, the objective and the requirement of QA in Macau higher education system. The regulation covers QA issues on both the institution and programme levels. In this study, only the programme levels will be discussed. In brief, an higher education institution should be accredited under an external accrediting agencies as there is no official accrediting agency in Macau. While for the programme level, current programmes of all postgraduate, undergraduate, and sub-degree levels are required to have Programme Review within 7 years the Regulations is in effect. More than half of the total number of the programmes should be reviewed within 4 years. The higher education institutions need to submit a self-evaluation report per programme to the External Accrediting Agency. Evaluation is a system- atic information gathering to support decision-making and learning (Scheerens, Glas, Thomas, \& Thomas, 2003). Since, the regulation is so new, in this study, I would like to investigate the general perception of QA in higher education students in Macau. Thus, the first research question is: RQ1: Students' self-reported perception on QA.

Some of the institutions in Macau have completed their pilot Institutional Accreditations, pilot and actual programme reviews and/ or programme accreditation. While for some smaller institutions, they are now working and preparing on programme review which is mandatory for current programmes. Since the programme review is mandatory and QA in higher education is in progress, they are affecting its stakeholders, and the mostly affected will be students. Here, I would like to explore how they perceive the importance of the programme being gone through academic accreditation, and in particular, if there are different views among students of career-related or non-related programmes.

RQ2: the perception of students on the importance of whether the programme being academically accredited.

Professional associations usually have a few functions such as providing examination for their potential members and continuous professional development programmes for their members. If a student wants to become a professional, $\mathrm{s} /$ he has to compete examination of professional associations and satisfy a few years of relevant work experience. Therefore, for students benefits, higher education institutions do seek accreditations from various relevant professional associations. In my earlier study, responding accounting students are required to rank professional accounting examination eligibility out of the other eight criteria. The question asked the participants to rank the importance of a set of nine employment selection criteria for the recruitment of entry-level accounting graduates. Students rank the eligibility on taking professional examination as the number one factor which means they perceive that their future employers are placing great emphasis on whether the person they hire should have the eligibility to take the professional examination. This give an implication that educators may need to make their programme more accessible to local or international professional examination, especially on career-related vocational programme (Cheung, 2019b).

Meanwhile, for the society as a whole, a QA system helps to develop trained and well-informed human capital. The idea to make Macau a centre of education excellence in Greater Bay Area is being advanced through proper planning and development in QA system. Through the development of 
trained, well-informed and state-of-the-art human capital, Macau is going to be transformed into a high-income city. To attract international/Mainland students to Macau, the government realizes the importance of branding Macau education, so to emphasizes more on lifestyle, culture and quality of education. In order to be competitive in international market, Macau is aware of the need to team up with China and other countries. The new regulations on higher education have given opportunities of all stakeholders to conduct dual degrees awarded programme with local and nonlocal collaboration. Meanwhile, in order to be more internationally competitive, especially in the fields strongly connected with a profession, higher education institutions in Macau can get their programmes accredited by related professional associations. Nowadays, graduates from the higher education institutions do not automatically imply that they possess the skills and knowledge necessary for their chosen career (Allen \& Van der Velden, 2007; Swanzy \& Potts, 2017). Therefore, in this study, I would like to investigate:

RQ3: the perception of students on the importance of whether the programme being accredited by professional association(s).

For QA in higher education, one of the elements of QA is: what is taught. And the other two are: who is taught, and who teaches (Skolnik, 2016). Ultimately, students will go into the workforce. We would like to know their perception on whether what they learnt will satisfy their work requirements. Students will be prompted to study the latest solutions to technical challenges in the market and experience how industry players think and act (Rajadurai et al., 2018; Rosier et al., 2016). According to human capital economists, education and training investment is useful to social and economic upward mobility and social climbing (Aleandri \& Refrigeri, 2013). Thus we have:

RQ4: the perception of students on the importance of their programme curriculum matched with the respective vocational/ job requirements?

To study this research question further, the questions break down into:

RQ4a: if there are different views among students studying at the four different programmes.

RQ4b: if there are different views among students working in a local Macau based company or a company operating also in other countries.

\section{Methodology}

Adopting a quantitative research method, a survey was administrated to students in one higher education institution in Macau. That higher education institution mostly offers career-related vocational programmes. Positions of higher vocational education and training in tertiary systems are often low in the hierarchy (Webb et al., 2017). Convenience sampling was adopted. The questionnaire is in Chinese. the questionnaire set including a 2- page questionnaire with a page of statement stating that this study concerns Macau QA in higher education, was distributed to students during 30 October and 3 December 2019. It is an anonymous questionnaire and the author is not in the classroom when the students filled in the questionnaires. I have distributed in total 144 questionnaire to students and usable questionnaires are 123, while some students do not answer all questions so there is some variations in between questions (RQ1, $N$ = 121; RQ2-4, $N=123$ ). Responding students are in four programmes, namely: accounting, facility management, human resources management and management. Among these programmes, the first three are considered as relating/ focusing in one particular field of professional area while management is a less career-related programme.

One question was designed to check the eligibility of the participants. The question checks whether the participants are studying or studied in the said higher education institution. Only when the answer was positive was the participant eligible for this research and allowed to complete the remaining part of the questionnaire. Then, participants are required to rate the importance of a set of questions about academic \& professional accreditation, curriculum and their perception of QA in higher education sector. Lastly, with five demographic questions which are about gender, age group, the programme the respondent is studying/studied, the size and the geographic area of operation of the company the respondent is working for.

The data was analysed through statistical tests using SPSS (version 20) and using descriptive statistics including frequencies, descriptive and crosstabs.

\section{RESULTS}

Table 1 shows the frequency for self-reported perception on QA knowledge from the students of that higher education institute. It relates to $\mathrm{RQ} 1$, which asked respondents to what extend they perceive their knowledge on QA in the context of higher education. A scale from 1 to 5,1 being the lowest, expresses as "Never heard of QA"; and the second lowest as " Heard QA before, but don't know what it is"; and the third, as "Heard QA, know it is related to programme review or programme accreditation"; the fourth, with some understanding, as "Heard, and know it is about 
programme review or programme accreditation, in addition, know the higher education institutions are required to go through institutional quality audit"; and the fifth , the highest scale in this study, as "In addition to the above, know existing programmes are required to go through programme reviews and new programmes have to go through programme accreditations. And, by 2025, every institution has to go through an institutional quality audit".

TABLE 1. Frequency for self-reported perception of knowledge on QA

\begin{tabular}{|c|c|c|c|}
\hline & Frequency $(N=121)$ & $\%$ & Accumulated \% \\
\hline Never Heard of "QA" & 38 & 31.4 & 31.4 \\
\hline Heard "QA" before, but don't know what it is. & 22 & 18.2 & 49.6 \\
\hline Heard "QA", know it is related to programme review or programme accreditation. & 31 & 25.6 & 75.2 \\
\hline $\begin{array}{l}\text { Heard, and know it is about programme review or programme accreditation, in addi- } \\
\text { tion, know higher education institution is required to go through institutional quality } \\
\text { audit. }\end{array}$ & 23 & 19.0 & 94.2 \\
\hline $\begin{array}{l}\text { On top of the above, know existing programmes are required to go through pro- } \\
\text { gramme reviews, and new programmes need to go through programme accredita- } \\
\text { tions. And, by } 2025 \text {, every institution has to go through an institutional quality audit. }\end{array}$ & 7 & 5.8 & 100 \\
\hline Total & 121 & 100 & \\
\hline
\end{tabular}

The QA issues in higher education had just been introduced in 2018 in Macau and the study took place in 2019, it is not surprisingly that nearly half of the students $(49.6 \%)$ responded in the first two categories (Never heard of QA, or Heard QA before, but don't know what it is). On the other hand, it can be said that there are another half of the responding students heard about QA and know it is related to programme review or programme accreditation.
For the following questions, Likert scale of 5 is used, 1 is the "not at all important", 2 is "not important", 3 is "neither important nor not important". 4 is "important", and 5 is "very important". The next question about RQ2, studies about the students' perception on the importance of their programmes being academically accredited. The results show in Table 2 and there is no response on "not at all important" (Likert scale 1).

TABLE 2. Percentage distribution of students, on the importance of programmes being academically accredited, by programme

\begin{tabular}{|c|c|c|c|c|c|}
\hline \multirow[t]{2}{*}{ Programme } & \multirow[t]{2}{*}{ Frequency $N=123$} & \multirow{2}{*}{$\begin{array}{l}\text { "Not Important" \& “Nei- } \\
\text { ther Important Nor Not } \\
\text { Important" (\%) }\end{array}$} & \multicolumn{3}{|c|}{ Important and Very Important } \\
\hline & & & Total (\%) & Important (\%) & Very Important (\%) \\
\hline Accounting & 40 & 27.5 & 72.5 & 37.5 & 35.0 \\
\hline Facility Management & 27 & 22.2 & 77.8 & 48.1 & 29.6 \\
\hline Human Resource Management & 20 & 20.0 & 80.0 & 50.0 & 30.0 \\
\hline Sub-total & 87 & $24.1 \%$ & 75.8 & 43.7 & 32.1 \\
\hline Management & 36 & 41.7 & 58.3 & 27.8 & 30.6 \\
\hline Total & 123 & 29.3 & 70.7 & 39.0 & 31.7 \\
\hline
\end{tabular}

For all responding students, $70.7 \%$ of them responded that their programmes had gone through the academic accreditation is important or very important. This finding is in line with Wilby et al. (2019) study. The participants of their study perceive that the accreditation provides opportunities related to careers and postgraduate studies, though in their study the accreditation refers to international accreditation. In this study, over $75 \%$ of the responding students of the following three career-related vocational programmes: accounting (72.5\%), facility management (77.8\%) and human resources management (80\%) viewed the programme had gone through the academic accreditation is very important. While their counterpart, management students, only
$58.3 \%$ viewed that it is important. Management is considered as a more general or less "career-related" programme in this research, it is possible to say that comparatively, students studying at a career-related vocational programme perceive it is more important to have the programme accredited.

Table 3 shows the perception of students on the importance of the programmes being accredited by professional associations. It relates to RQ3. Again, no one responds "not at all important". Among the four programmes, accounting has the longest history on professional accreditation. There are many accounting professional associations over the world and they usually give exemption or ac- 
creditation to relevant accounting programmes. There are over $82 \%$ (the highest among all programmes) responding students consider it is very important or important to have their programmes accredited by professional associations. Facility management has also got $74 \%$, being the second highest. While the management, it only has $60 \%$. Over $77 \%$ of the responding students of the three careerrelated vocational programmes viewed important and very important for this question. The results are in line with earlier literature-in Blumenstyk (2018), Blumenstyk (2019) studies, both the students and the institution can get benefits from the professional certification (where certification should have gone through third party verification of skills) that demonstrate industry-specific skills. More and more recruiting managers have increased interest in hiring candidates with professional certification as these certifications represent a third-party verification of skills (Adams et al., 2004; Ramamonjiarivelo, Lieneck, Kruse, Greene, \& Fulton,
2020; Raymond, 2001). In my study, I did not ask the reasons behind why they viewed it is important or very important to have the programmes being accredited (professional or academic). However, students might view professional accreditations could assist in their employability.

To sum up the results from RQ2 and RQ3, 70.7\% and $72.4 \%$ responding students respectively perceive it is important to have their programmes gone through the academic accreditation and professional accreditation. The majority of vocational education training providers indicated that quality is important (Gatt \& Faurschou, 2016). Accreditation is a kind of QA process. Although, the respondents in my study are students and in their study are education providers, both of them are the main stakeholders in higher education - students are the users and the education providers are the suppliers. Results of this study and their study are in line, the majority respondents of both studies indicated that quality is important.

TABLE 3. Percentage distribution of higher education students according to the perception of the importance of programme being accredited by professional association(s), by programme

\begin{tabular}{|c|c|c|c|c|c|}
\hline \multirow[t]{2}{*}{ Programme } & \multirow[t]{2}{*}{ Frequency $N=123$} & \multirow{2}{*}{$\begin{array}{l}\text { "Not Important" \& "Nei- } \\
\text { ther Important Nor Not } \\
\text { Important" (\%) }\end{array}$} & \multicolumn{3}{|c|}{ Important and Very Important } \\
\hline & & & Total (\%) & Important (\%) & Very Important (\%) \\
\hline Accounting & 40 & 17.5 & 82.5 & 47.5 & 35.0 \\
\hline Facility Management & 27 & 25.9 & 74.1 & 48.1 & 25.9 \\
\hline Human Resource Management & 20 & 30.0 & 70.0 & 35.0 & 35.0 \\
\hline Sub-total & 87 & 23 & 77.0 & 44.8 & 32.2 \\
\hline Management & 36 & 38.9 & 61.1 & 27.8 & 33.3 \\
\hline Total & 123 & 27.6 & 72.4 & 39.8 & 32.5 \\
\hline
\end{tabular}

For the following two questions, they related to RQ4a \& $4 \mathrm{~b}$, shown on Table 4 , again, there is no response on "not at all important" and "not important". Overall, 88.6\% (by programme, from $80.6 \%$ to $95 \%$ ) of the responding students viewed that they agree or strongly agree the curriculum should satisfy its respective professional/job needs. Higher education programme, the curriculum is clean fit with the professional certification/accreditation (Ramamonjiarivelo et al., 2020) Education providers should bear in mind that the curriculum design should be relevant to professional/job related requirements. Accounting students did express a strong view (95\% of "important" and "very important") emphasizing the curriculum should match the accounting jobs needs. Accounting programme has a tradition to be career-related/career-focused. Further to the responses got from accounting students, if look at the other career-related programmes, there is an aggregate of $92 \%$ respondents consider important and very impor- tant while their counterpart management students is only $80.6 \%$. Thus, on this matching of curriculum and professional needs, education providers of career-related programmes might need to take this implication seriously.

Table 5 shows the data of the same question, but presented by the geographical area of operation of the respondent's company. We find that over $90 \%$ (company with operation only in Macau) and 86.2\% (company with operation in Macau and other countries) of responding students says important and very important in this question. In fact, there is not much difference between these two groups. As the difference is not much, we may conclude that the geographic area of operation does not affect much on the programme curriculum matching to the respective vocational needs. 
TABLE 4. Percentage distribution of higher education students according to their perception of the curriculum of studying programmes satisfied respective professional/job needs, by programmes

\begin{tabular}{llllll}
\hline \hline Programme & Frequency $\boldsymbol{N = 1 2 3}$ & \multicolumn{2}{l}{$\begin{array}{c}\text { "Neither Important Nor } \\
\text { Not Important" (\%) }\end{array}$} & \multicolumn{2}{l}{ Important and Very Important } \\
\cline { 3 - 6 } & & & Total (\%) & Important (\%) & Very Important (\%) \\
\hline Accounting & 40 & 5.0 & 95.0 & 65.0 & 30.0 \\
Facility Management & 27 & 11.1 & 88.9 & 59.3 & 29.6 \\
Human Resource Management & 20 & 10.0 & 90.0 & 70.0 & 20.0 \\
Sub-total & 87 & 8.0 & 92.0 & 64.4 & 27.6 \\
Management & 36 & 19.4 & 80.6 & 47.2 & 33.3 \\
Total & 123 & 11.4 & 88.6 & 59.3 & 29.3 \\
\hline \hline
\end{tabular}

TABLE 5. Percentage distribution of higher education students according to their perception of the programme curriculum matched with their respective vocational needs, by geographical area of operation (Macau only and Macau \& other countries)

\begin{tabular}{llllll}
\hline \hline Geographical Area of operation & Frequency $\boldsymbol{N}=\mathbf{1 2 3}$ & \multicolumn{2}{c}{$\begin{array}{l}\text { “Neither Important Nor } \\
\text { Not Important” (\%) }\end{array}$} & \multicolumn{3}{l}{ Important and Very Important } \\
\cline { 3 - 6 } & & & Total (\%) & Important (\%) & Very Important (\%) \\
\hline Macau only & 65 & 9.2 & 90.8 & 67.7 & 23.1 \\
Macau and other countries & 58 & 13.8 & 86.2 & 51.7 & 34.5 \\
Total & 123 & 11.4 & 88.6 & 60.2 & 28.5 \\
\hline \hline
\end{tabular}

\section{DISCUSSION}

In this exploratory study, I found two major results and with implication for the Covid-19 situation. First, there is over three quarters of responding career-related vocational programmes students perceived it is important/very important to have their programmes being academic (RQ2) or professional (RQ3) accredited, while their counterparts management students are about $60 \%$. Accounting is regarded as a career-related vocational programmes. $\mathrm{RQ3}$, it is about professional accreditation, accounting students (82.5\%, being the highest) perceive that it is important/very important to have their programmes being accredited by professional associations. The high percentage (82.5\%) echoed with my previous study which asks higher education accounting students to rank among nine recruitment selection criteria. The study is about hiring decision on an entry-level accounting graduates. Students rank "professional accounting examination eligibility" as number 1 . Students perceive their future employers placing great emphasis on the eligibility on whether they are able to take professional examination. Having the eligibility to take a professional association examination means that the programme itself should have been previously accredited by that professional association. There is a need to make their programme more accessible to local or international professional examination, especially on vocational -based programmes (Cheung, 2019a). Ramamonjiarivelo et al. (2020) study also supports the result. Professional certification enhance graduate's competitions in a job search, because knowledge and expertise of the subject matter (p.27). The accreditation of programmes is used by many universities to market their accounting degrees and is seen as an important influence on recruitment (Ellington \& Williams, 2017). Questions asked in these studies are different but the implication of the results are similar. Hong Kong accounting students perceive their future employers do take the eligibility of professional examination the most important criterion and Macau students (82.5\%) perceive important/very important on accreditation of their programme. Accounting students in both studies do find their programme accredited by professional association are important.

A secondary finding indicates that all responding students (88.6\%) require their programme curriculum matched with the respective profession/job needs. The result is supported by Ramamonjiarivelo et al. (2020) study, they find that graduates are more marketable when the requirements of the professional certifications infused into the programme curriculum. Further, it is found that students studying in career-related programme take more seriously in this curriculum matched with job requirements than those studying in non-career related (management) programmes. The vocational based higher education institutions under the dual function of knowledge and practice, should bear a responsibility to educate all-embracing talents to allow suitable curriculum setting to educate more career-related vocational students to adapt to this era (Cheung, 2020).

At the time of writing this paper, the world has been in pandemic mode for more than half a year. Macau in the past has a very low unemployment rate as $2 \%$, but after the outbreak of Covid-19, unemployment rate rise and the requirements of certain jobs have been changed. For example, teaching 
changes from face-to-face teaching mode to mostly online. It is expected a number of job requirements will be changed or permanently changed since the outbreak of Covid-19, and in fact, it has been evolving. With the insights got from the results of RQ4, students do expect the programme curriculum (especially career-related) be matched with the respective job requirements. All the students in this study are adult, and they would be affected by this pandemic and their voices on job related issues should be heard.

\section{CONCLUSION}

In the context of $\mathrm{QA}$, the higher education system in Macau is in the learning stage. As said, QA in Macau education field is very young, strictly speaking, it starts in 2018 when the regulation No. 17/2018 took effect in August 2018. In practice, accreditation by professional associations is a kind of QA process, the professional associations will monitor the programmes, and continuously evaluate if the programmes should be carried with the same accreditation status. Nearly half of the respondents, self-reported that they do not know what is QA but over 70\% of them perceive it is important and very important to have their studying programmes being academic accredited (RQ2) or Professional accredited (RQ3). They do in fact welcome the QA process though they do not very understand the term of QA. Also, career-related programme students, comparing to non-career-related students, they prefer to have their programme being academic or professional accredited. Education providers should note that even newer career-related programme students they do prefer the programme ac- credited by professional association (facility management, $74.1 \%$ ). Because in this era of lifelong learning, higher education institutions should bear a responsibility to provide more opportunity to students for their survival in future.

\section{LIMITATIONS AND RECOMMENDATIONS}

As it is an exploratory and small study, it is recommended that a further examination of the topic, using respondents from other higher education institutions in Macau. Moreover, Students can be from different programmes. Furthermore, the study has only taken one higher education institution student data, similar study can be conducted in 3 to 5 years from the introduction of this QA system in higher education in Macau and see if there is any improvement for students' perception.

The findings imply that development of QA in Macau can ensure healthy growth and competitiveness of Macau's higher education institutions, especially those are private and smaller ones. It is because all programmes and institutions themselves have to go through a tough and recognized QA standard. Having passed the mandatory required standard, the outcomes can prove the programmes attained required standard and give stakeholders confidence. Lastly, students' voices on having programme curriculum matched with job requirements should be heard in this pandemic mode as re-training is an issue on this downturn of economy and soaring unemployment rate.

\section{ACKNOWLEDGMENT}

This research was support by Macao Foundation. And, thanks those students.

\section{REFERENCES}

Adams, P. S., Brauer, R. L., Karas, B., Bresnahan, T. F., \& Murphy, H. (2004). Professional certification. Professional Safety, 49(12), 26-31.

Aleandri, G., \& Refrigeri, L. (2013). Lifelong learning, training and education in globalized economic systems: Analysis and perspectives. Procedia-Social and Behavioral Sciences, 93, 1242-1248. doi:https://doi.org/10.1016/j.sbspro.2013.10 .022

Allen, J., \& Van der Velden, R. (2007). Transitions from higher education to work. In, Careers of university graduates. London, UK: Springer.

Alves, J. C., Lok, T. C., Luo, Y., \& Hao, W. (2020). Crisis management for small business during the COVID-19 outbreak: Survival, resilience and renewal strategies of firms in Macau. Retrieved from https://bit.ly/3luYuEf

Ansah, F. (2015). A strategic quality assurance framework in an African higher education context. Quality in Higher Education, 21(2), 132-150. doi:https://doi.org/10.1080/13538322.2015.1084720

Avis, J. (2012). Global reconstructions of vocational education and training. Globalisation, Societies and Education, 10(1), 1-11. doi:https://doi.org/10.1080/14767724.2012.646876

Biggs, J. (2001). The reflective institution: Assuring and enhancing the quality of teaching and learning. Higher Education, 41(3), 221-238. doi:https://doi.org/10.1023/A:1004181331049

Blumenstyk, G. (2018). One way to set up liberal-arts majors for success: Focus on skills. The Chronicle of Higher Education, 5(1), 1-14. 
Blumenstyk, G. (2019). Why isn't it a no-brainer to embed "certifications" into bachelor's degrees? Retrieved from https:// bit.ly/2IhrDEH

Cheung, R. W. Y. (2019a). Hiring decisions of entry-level graduates: Does professional accreditation matter? Perception gaps between accountants and students. International Journal of Business and Economic Affairs, 4(6), 293-299. doi: https://doi.org/10.24088/IJBEA-2019-46004

Cheung, R. W.-Y. (2019b). Vocational education students'perception on ethics study: Evidence from accounting students. International Journal of Social Sciences, 5(3), 345-356. doi:https://doi.org/10.20319/pijss.2019.53.345356

Cheung, R. W.-Y. (2020). Ethics study in professional and vocational education: Voices from practitioners. International Journal of Humanities, Arts and Social Sciences, 6(2), 63-68. doi:https://dx.doi.org/10.20469/ijhss.6.20001-2

Di Rienzo, P. (2019). Accreditation of prior experiential learning and vocational education. Research and Development, 6(8), 67-80.

Elassy, N. (2015). The concepts of quality, quality assurance and quality enhancement. Quality Assurance in Education, 5(7), 67-80.

El-Khawas, E. (2013). Quality assurance as a policy instrument: What's ahead? Quality in Higher Education, 19(2), 248-257. doi:https://doi.org/10.1080/13538322.2013.806740

Ellington, P., \& Williams, A. (2017). Accounting academics' perceptions of the effect of accreditation on UK accounting degrees. Accounting Education, 26(5-6), 501-521. doi:https://doi.org/10.1080/09639284.2017.1361845

Gatt, S., \& Faurschou, K. (2016). Implementing the European Quality Assurance in Vocational Education and Training (EQAVET) at national level: Some insights from the PEN leonardo project. International Journal for Research in Vocational Education and Training, 3(1), 29-45. doi:https://doi.org/10.13152/IJRVET.3.1.3

Gjorgov, E., \& Cripps, J. (2018). The accredited university of tomorrow: Accreditation, creativity and international recognition. China-USA Business Review, 13(9), 100-114. doi:https://doi.org/10.17265/1537-1514/2018.02.005

Gössling, S., Scott, D., \& Hall, C. M. (2020). Pandemics, tourism and global change: A rapid assessment of COVID-19. Journal of Sustainable Tourism, 6(1), 1-20. doi:https://doi.org/10.1080/09669582.2020.1758708

Grapragasem, S., Krishnan, A., \& Mansor, A. N. (2014). Current trends in malaysian higher education and the effect on education policy and practice: An overview. International Journal of Higher Education, 3(1), 85-93.

Hanh, N. D., Nga, N. T. M., Loan, V. Q., \& Viet, N. M. (2019). Role of quality assurance and quality accreditation in higher education in some developing countries and Vietnam. American Journal of Educational Research, 7(9), 649-653. doi: https://doi.org/10.12691/education-7-9-8

Harvey, L. (2011). Analytic quality glossary, quality research international. Quality International Journal, 6(8), 34-60.

Higher Education Bureau. (2019). Seizing opportunities and marching forward together - development of higher education after the establishment of the macao special administrative region. Retrieved from https://bit.1y/31wEWPJ

HM Government. (2017). Building our industrial strategy. Retrieved from https://bit.1y/3luzQDK

Keniry, L. J. (2020). Equitable pathways to 2100: Professional sustainability credentials. Sustainability, 12(6), 23-28. doi: https://doi.org/10.3390/su12062328

Knight, J. (2003). Gats, trade and higher education perspective 2003-where are we? Retrieved from https://bit.1y/ $31 \mathrm{XZsQ5}$

Köpsén, J. (2020). Employers placing orders and students as commodities: Swedish post-secondary vocational education and training policy. Journal of Vocational Education \& Training, 6(8), 1-20. doi:https://doi.org/10.1080/13636820 .2020 .1744695

Lester, S. (2015). A vocational qualifications system fit for adults? revisiting some ideas from the university for industry. Higher Education, Skills and Work-based Learning, 6(8), 67-89.

Mandal, S. (2013). From policy to guidelines: Metamorphosis of lifelong learning in India. International Journal of Lifelong Education, 32(2), 190-208. doi:https://doi.org/10.1080/02601370.2012.733973

Marginson, S. (2016). The worldwide trend to high participation higher education: Dynamics of social stratification in inclusive systems. Higher Education, 72(4), 413-434. doi:https://doi.org/10.1007/s10734-016-0016-x

Meidrina, T., Mawaddah, S. N., Siahaan, F. M. M., \& Widyasari, P. (2017). The relationship between teacher efficacy and attitude towards inclusive education in private elementary school: A study based on teaching experiences. Journal of Advances in Humanities and Social Sciences, 3(3), 124-134. doi:https://doi.org/10.20474/jahss-3.3.1 
Ooro, S. A. (2013). Creativity within the higher education system. Interdisciplinary Studies Journal, 2(3), 47-60. doi:https:// doi.org/10.1.1.472.9813

Orrell, B., Bishop, M. M., \& Hawkins, J. (2020). A road map to reemployment in the covid-19 economy. Retrieved from https: // bit.ly/2I8aVHA

Owusu-Agyeman, Y. (2017). Expanding the frontiers of national qualifications frameworks through lifelong learning. International Review of Education, 63(5), 657-678. doi:https://doi.org/10.1007/s11159-017-9661-2

Rajadurai, J., Sapuan, N. M., Daud, S., \& Abidin, N. (2018). The marketability of technical graduates from Higher Educational Institutions (HEIs) offering Technical and Vocational Education and Training (TVET): A case from Malaysia. The Asia-Pacific Education Researcher, 27(2), 137-144. doi:https://doi.org/10.1007/s40299-018-0372-7

Ramamonjiarivelo, Z., Lieneck, C., Kruse, C. S., Greene, L., \& Fulton, L. (2020). Assessing the impact of professional certifications on time-to-hire, job satisfaction, and career growth of health administration alumni. The Journal of Health Administration Education, 37(1), 25-36.

Raymond, M. R. (2001). Job analysis and the specification of content for licensure and certification examinations. Applied Measurement in Education, 14(4), 369-415. doi:https://doi.org/10.1207/S15324818AME1404_4

Reuters. (2020). Macau's leader warns of over reliance on gaming industry in wake of COVID-19. Retrieved from https:// reut.rs/34LEfv4

Rosier, J., Slade, C., Perkins, T., Baldwin, C., Coiacetto, E., Budge, T., \& Harwood, A. (2016). The benefits of embedding experiential learning in the education of planners. Planning Practice \& Research, 31(5), 486-499. doi:https://doi.org/ 10.1080/02697459.2016.1229899

Ryan, M., Gwinner, K., Mallan, K., \& Livock, C. (2017). Preparing work-ready nurses: Reflexive learning for diverse students in the Australian vocational education and training sector. Studies in Continuing Education, 39(3), 268-285. doi:https:// doi.org/10.1080/0158037X.2017.1279136

Scheerens, J., Glas, C. A., Thomas, S. M., \& Thomas, S. (2003). Educational evaluation, assessment, and monitoring: A systemic approach. New York, NY: Taylor \& Francis.

Skolnik, M. L. (2016). How do quality assurance systems accommodate the differences between academic and applied higher education? Higher Education, 71(3), 361-378. doi:https://doi.org/10.1007/s10734-015-9908-4

Swanzy, P., \& Potts, A. (2017). Quality assurance strategies in higher education: The case of Ghanaian polytechnics. Education Research and Perspectives, 44(6), 100-140.

Webb, S., Burke, P. J., Nichols, S., Roberts, S., Stahl, G., Threadgold, S., \& Wilkinson, J. (2017). Thinking with and beyond bourdieu in widening higher education participation. Studies in Continuing Education, 39(2), 138-160. doi:https:// doi.org/10.1080/0158037X.2017.1302926

Wilby, K. J., Alamri, M., \& Monfared, S. (2019). Student and graduate perceptions regarding canadian-based accreditation of a pharmacy program in Qatar. American Journal of Pharmaceutical Education, 83(6), 89-100.

Yulastri, A., Hidayat, H., Ganefri, G., Edya, F., \& Islami, S. (2018). Learning outcomes with the application of product based entrepreneurship module in vocational higher education. Jurnal Pendidikan Vokasi, 8(2), 120-131. doi:https://doi .org/10.21831/jpv.v8i2.15310 